\title{
APLIKASI PENCARIAN SPBU MINI DAN BENGKEL MENGGUNAKAN METODE LOCATION BASED SERVICE PADA KECAMATAN LOWOKWARU MALANG BERBASIS ANDROID
}

\author{
Joi Masini, Yosep Agus Pranoto, Nurlaily Vendyansyah \\ Program Studi Teknik Informatika S1, Fakultas Teknologi Industri \\ Institut Teknologi Nasional Malang, Jalan Raya Karanglo km 2 Malang, Indonesia \\ joymasini@gmail.com
}

\begin{abstract}
ABSTRAK
Dalam hal mencari lokasi tempat SPBU mini ini masih sulit, masyarakat hanya dapat bertanyaan kepada orang sekitar ataupun browsing lewat internet saja dan juga masyarakat hanya mengetahui SPBU umum. Mencari informasi tersebut tidak tepat, dan juga terkadang keliru mencari jalur yang di tentukan oleh internet. Beberapa orang yang belum mengetahui adanya SPBU mini di daerah - daerah jalan trobosan atau wilayah selain perkotaan. Untuk layanan service yaitu bengkel motor ini juga sebagian orang khusus nya wilayah kecamatan lowokwaru malang belum mengetahui adanya bengkel tersebut, biasa orang bepergian dan mengalami kerusakan motor di jalan. Orang tersebut harus mencari bengkel untuk memperbaiki motornya.

Penulis akan membuat aplikasi dimana aplikasi ini akan mencari tempat SPBU mini dan bengkel service kendaraan yang berada disekitar wilayah kecamatan lowokwaru malang. Hasil pengujian yang telah dilakukan yaitu dari ( Metode Location Based Service ), untuk mengetahui pencarian lokasi “ SPBU MINI dan Bengkel motor " diperoleh hasil yang sesuai dari aplikasi android. User mendapatkan lokasi SPBU MINI dan bengkel.

Dari proses dan juga hasil pengujian aplikasi ini, bahwa penulis membuat aplikasi berbasis android. Hasil implementasi aplikasi ini yaitu di operasikan di smartphone android, untuk mempermudah dan membantu pengguna kendaraan dalam mencari tempat SPBU mini dan bengkel service.
\end{abstract}

Kata Kunci : Aplikasi Pencarian, Spbumini Dan Bengkel, Location Based Service

\section{PENDAHULUAN}

Pada layanan pemerintah yaitu SPBU mini dan bengkel motor roda dua, disediakan secara umum. Pada wilayah Kecamatan Lowokwaru Malang, SPBU tersebut menjadi salah satu fasilitas penunjang sebagai bahan bakar kendaraan untuk kelancaran mobilitas transportasi. Sebagai kota terbesar kedua di daerah jawa Timur, kecamatan Lowokwaru Malang memiliki 19 SPBU, yang total jumlahnya tersebar pada wilayah Kecamatan Lowokwaru. Di Malang, tidak semua SPBU tersebut dimiliki oleh pertamina sebagai perusahaan operator sekaligus distributor bahan bakar di Indonesia. Adapun juga SPBU yang dikelolah oleh pertamina memiliki area yang lebih luas di bandingkan SPBU dengan luas tempat yang kecil.

Untuk menarik setiap pelanggan, biasanya SPBU Malang tersebut berlomba membangun fasilitas tambahan yaitu, seperti tempat pengisian angin, tambal ban mobil dan motor, alat radiator, temapt mushola, toilet umum, ATM, rest area, minimarket dan juga food court. Fasilitas serba lengkap yang tersedia itu biasanya hanya ada di SPBU besar saja. Karena dalam hal persaingan yang ketat dalam merebutkan pelanggan, beberapa SPBU terutama yang sifatnya relatif rendah, akibatnya gulung tikar. Seperti contoh, SPBU kecil yang berada di jalan Kalimantan, yang kini sangat terbengkala. Termasuk juga SPBU pojokan di bundaran SMP Negeri 5 yang sempat menjadi sengketa. kedua SPBU tersebut kini sudah tak beroperasi lagi.

\section{TINJAUAN PUSTAKA}

\subsection{Penelitian Terkait}

Edy Budiman, pada tahun 2016 melakukan penelitian dengan judul "Pemanfaatan Teknologi Location Based Service Dalam Pengembangan Aplikasi Profil Kampus Universitas Mulawarman Berbasis Mobile". Pada penelitian tersebut terdapat sebuah masalah yaitu, luasnya kampus Universitas Mulawarman membuat setiap masyarakat umum yang belum sama sekali mengenal mengenai Kampus Gunung Kelua maupun yang telah lama tidak pernah pergi berkunjung ke Kampus Gunung Kelua akan merasa kesulitan dalam mencari tempat atau bangunan yang berada di Kampus Gunung Kelua serta berbagai program studi, jurusan, fakultas dan fasilitas pendukungnya. Metode yang digunakan untuk mengatasi permasalah itu adalah Layanan Berbasis Lokasi atau lebih dikenal dengan Location Based Service (LBS) istilah umum yang digunakan untuk menggambarkan teknologi yang digunakan untuk menemukan lokasi perangkat yang kita gunakan. LBS adalah layanan informasi yang dapat diakses melalui mobile device dengan menggunakan mobile network, yang dilengkapi kemampuan untuk memanfaatkan lokasi dari mobile device tersebut. Hasil dari penelitian menunjukkan bahwa pada pemanfaatan teknologi Location Based Service dalam 
pengembangan aplikasi profil kampus universitas mulawarman memadukan teknologi Geographic Information System, Internet Service, dan Mobile Devices ini membantu memberikan informasi profil dan lokasi fakultas serta fasilitas-fasilitas di Universitas Mulawarman secara mudah, cepat dan akurat.[1]

Badrul Anwar, dkk pada tahun 2014 melakukan penelitian dengan judul "implementasi location based service berbasis android untuk mengetahui posisi user". Pada penelitian tersebut terdapat sebuah permasalahan yaitu, untuk pencarian lokasi sangatlah penting, hal itu dinilai dari permasalahan yang timbul tanpa menggunakan sistem pencarian lokasi, antara lain adalah seseorang tidak dapat mencari di mana posisi ia berada sekarang dan mungkin saja seseorang tersebut akan tersesat. Metode yang digunakan untuk mengatasi permasalahan itu adalah Location Based Service (LBS) adalah sebuah service untuk memberikan informasi sesuai lokasi kita berada. Contohnya menunjukan titik terdekat dari kita, seperti ATM, SPBU, dan Rumah Sakit, bahkan juga lokasi seseorang. Hasil penelitian menunjukkan bahwa Dengan menganalisa dan merancang aplikasi pencarian lokasi user maka tersedia aplikasi yang memberikan informasi seputar keberadaan user.[2]

Khaidir Ali, pada tahun 2017 melakukan penelitian dengan judul " Aplikasi pencarian tempat ibadah menggunakan metode Location Based Service berbasis android ". Pada penelitian tersebut terdapat sebuah permasalahan yaitu, Tempat ibadah sebuah tempat yang digunakan oleh umat beragama untuk beribadah menurut ajaran agama atau kepercayaan mereka masing-masing. Namun sering kali para pendatang kesulitan dalam menemukan lokasi tempat ibadah. Ditambah lagi dengan kondisi lalu-lintas di kota malang yang relatif padat ketika jam tertentu. Tentu saja akan menghabiskan banyak waktu untuk mencari dan menuju lokasi tempat ibadah yang akan dituju. Sehingga waktu akan terbuang sia-sia selama diperjalanan. Metode yang digunakan untuk mengatasi permasalah itu adalah metode location based service, yaitu berdasarkan beberapa masalah di atas, maka untuk membantu pendatang dalam menemukan lokasi tempat ibadah, dibangunlah sebuah aplikasi layanan berbasis lokasi (Location Based Service). Aplikasi ini nantinya dapat memberikan informasi tentang lokasi tempat ibadah. Melalui Google Maps API dan dapat menampilkan jadwal berbasis lokasi.[3]

Wiindi Eka Y, pada tahun 2015 melakukan penelitian dengan judul "pencarian spbu terdekat dan penentuan jarak terpendek menggunakan algoritma Dijkstra (studi kasus di kabupaten jember)" Pada penelitian tersebut terdapat sebuah permasalahan yaitu, Kabupaten Jember merupakan salah satu destinasi kota yang banyak objek wisatanya, sehingga tidak sedikit para wisatawan dari luar kota berdatangan dengan tujuan berwisata. Kota Jember juga merupakan akses utama jalur mudik karena
Kabupaten Jember merupakan salah satu pusat regional di kawasan tapal kuda, sehingga banyak pengendara kendaraan bermotor yang dari luar kota bepergian ke kota Jember baik untuk berkunjung ataupun berwisata. Di luar kota pengendara biasanya tidak begitu mengetahui letak SPBU, sehingga mereka kesulitan dalam menentukan harus ke mana dan melewati jalur mana yang lebih dekat untuk menuju SPBU. Metode yang digunakan untuk mengatasi permasalah itu adalah sistem informasi geografis berbasis web dapat mempermudah pengguna mengakses informasi lokasi SPBU dimana saja dan kapan saja serta dapat membantu pengguna dalam menentukan letak SPBU baru yang strategis . Rute terpendek juga pernah menjadi konsen penelitian Sofyan Arifianto, pada penelitian ini diaplikasikan penentuan rute terpendek pada jaringan multi moda transportasi umum menggunakan algoritma dijkstra. Algoritma dijkstra dianggap cocok karena mudah digunakan oleh user dalam penggunaannya hanya dengan menentukan titik awal dan titik tujuan. Hasil penelitian menunjukkan bahwa penentuan jalur terpendek juga dihitung dengan menggunakan software lain yaitu QuantumGIS. Hal ini dilakukan untuk melihat apakah jalur yang dihasilkan sudah benar. Dari hasil perbandingan didapatkan hasil bahwa jalur yang telah diperoleh sama dengan perhitungan QuantumGIS.[11]

\subsection{Kecamatan lowokwaru}

Daerah kota malang adalah sebuah kota yang terletak di Provinsi jawa timur setelah Surabaya, dan kota terbesar ke - 12 di Indonesia. Kota ini didirikan pada masa kerajaan kanjuruhan dan terletak didaratan tinggi seluas $145,28 \mathrm{~km}^{2}$ yang terletak di tengah tengah kabupaten malang. Bersama dengan kota batu dan kabupaten malang, kota malang merupakan bagian dari kesatuan malang raya. Kota malang memiliki berbagai macam orang dan berbagai macam suku bangsa dan budaya. Penduduk kota malang mencapai 895.387 jiwa dengan suku mayoritas jawa, diikuti dengan madura. Terlebih utama yaitu pada kabupaten malang untuk menjadi landasan sebagai wilayah daru aplikasi yang antinya dibuat. Pada kabupaten malang ini mempunyai 5 kecamatan, antara lain : kecamatan blimbing, kecamatan kedungkandang, kecamatan klojen, kecamatan lowokwaru dan kecamatan sukun. Kabupaten ini berbatasan secara langsung dengan kota malang yaitu pada tengah - tengahnya terdapat kabupaten jombang, kabupaten pasuruan dan kota batu dibagian utara. Pada kabupaten malang menjadi salah satu opjek dentinasi wisata utama di jawa timur. Bersamaan juga dengan kabupaten batu dan juga malang raya. Lowokwaru adalah sebuah kecamatan di kota malang, jawa timur. Kecamatan ini di sebelah utara berbatas dengan kecamatan karangploso, sebelah timur dengan kecamatan blimbing, selatan dengan kecamatan klojen dan barat dengan kecamatan dau. Daerah ini memiliki suhu minimum 
$20 \mathrm{C}$ dan maksimum $20 \mathrm{C}$ dengan curah hujan ratarata $2.71 \mathrm{~mm}$.

Ahmad Fahrizal Syamsi, pada tahun 2017 melakukan penelitian dengan judul “ Penerapan metode location base service untuk aplikasi tourism guide kabupaten sumba barat berbasis android ". Pada penelitian tersebut terdapat permasalahan yaitu, Banyak orang lebih mengenal pulau Lombok daripada pulau Sumbawa, bahkan kebanyak orang mengira provinsi nusa tenggara barat hanya dimiliki oleh pulau Lombok. Pulau Lombok terkenal dengan keindahan tempat wisatanya yang beragam, itulah salah satu yang membuat pulau Lombok lebih terkenal dari pada pulau Sumbawa . Metode yang digunakan untuk mengatasi permasalah itu adalah dengan menggunakan layanan berbasis lokasi atau lebih dikenal dengan Location Based Service (LBS) layanan ini merupakan layanan yang memberikan suatu informasi tertentu kepada penggunanya yang berdasarkan lokasi pengguna. Dengan adanya aplikasi ini diharapkan dapat membantu para wisatawan yang datang dan yang ingin berlibur ke Sumbawa dengam memanfaatkan aplikasi pemandu wisata (tourism guide) ini.[19]

Kecamatan lowokwaru terdiri dari 12 kelurahan yaitu :

1. Kelurahan Tunggulwulung

2. Kelurahan Merjosari

3. Kelurahan Tlogomas

4. Kelurahan Dinoyo

5. Kelurahan Sumbersari

6. Kelurahan Ketawanggede

7. Kelurahan Jatimulyo

8. Kelurahan Tunjungsekar

9. Kelurahan Mojolangu

10. Kelurahan Tulusrejo

11. Kelurahan Lowokwaru

12. Kelurahan Tasikmadu

\subsection{Location Based Service}

Location Based Service ataupun layanan berbasis lokasi adalah sebutan umum yang dipakai untuk mencitrakan teknologi yang dipakai untuk menunjukkan lokasi perangkat yang dipakai. Menurut Qusay H. Mahmoud, LBS adalah yaitu layanan yang dipakai untuk mengetahui lokasi dari pengguna, kemudian memakai informasi tersebut akan mempersiapkan pelayanan dan aplikasi yang personal. Dua unsur pokok LBS yaitu :

1. Location Manager (Api Maps)

Mempersiapkan tools/source kepada LBS, Application Programming Interface (API) Maps menyajikan fasilitas untuk menampilkan, memalsukan peta dengan fitur-fitur lainya semacam bentuk di satelit, jalan, ataupun gabungannya.

2. Location Providers (Api Location)
Pengguna dapat memilih lokasinya, melacak aktifitas/perpindahan, dan juga interelasi dengan posisi tertentu serta mengetahui perpindahan.

Secara umum, LBS dapat di kategorikan menjadi dua bagian, yaitu :

1. Pull Service: Layanan cuma dikasih selagi ada permintaan dari pengguna.

2. Push Service : Layanan dikasih langsung dari service provider tanpa menanti permintaan oleh pengguna.

Yang didirikan dari teknologi informasi dan komunikasi baru (New Information and Communication Technologies / NICTS) yang terdapat yaitu : system telekomunikasi mobile dan alat genggam, dengan data bermula dari internet dan Sistem Informasi Geografis (SIG) yang memakai spatial database.

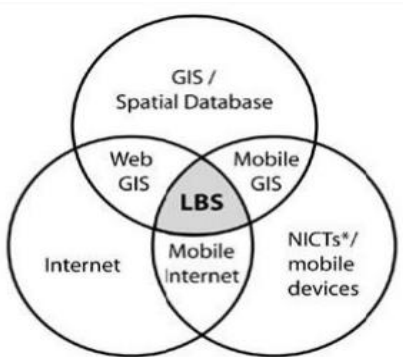

Gambar 2.1 Pola perpotongan Teknologi LBS (Jumriya, 2018)

Metode location based service ( LBS ), dapat dimodelkan dalam bentuk tiga lingkaran sebagai suatu model layanan yang berbeda pada pertemuan dari tiga model tersebut yaitu : Web Geographic Information System, mobile Geographic Information System dan mobile Internet. Dari teknologi Location Based Service berfokus bagaimana caranya untuk menentukan suautu posisi dari yang digunakan atau biasa disebut dengan metode positioning.

Di Dalam Layanan Berbasis Lokasi ditemukan 5 faktor yaitu :

1. Mobile Devices: adalah sebuah alat yang dipakai oleh pemakai untuk memperoleh informasi yang diinginkan. Informasi ini dapat di ambil dalam bentuk gambar, suara, dan teks.

2. Comunication Network: adalah jaringan komunikasi yang mengirim data user dan informasi yang diminta oleh mobile terminal ke Sevice Provider lalu memberikan kembali informasi yang telah diminta ke user. Communication Network bias juga berupa jaringa seluler (GSM, CDMA), Wireless Wide Area Network (WWAN), dan Wireless Local Area Network (WLAN)

3. Positioning Component: adalah mengoprasikan sebuah layanan oleh karna itu lokasi user harus diketahui. 
4. Service and Aplication Provider: Penyedia layanan menawarkan berbagai macam layanan kepada pengguna dan bertanggung jawab untuk memproses informasi yang diminta oleh pengguna.

5. Data and Content Provider: Penyedia layanan tidak selalu menyimpan semua data yang dibutuhkan yang bisa diakses oleh pengguna. Untuk itu, data dapat diminta dari data dan content provider.

\subsection{Google Maps API}

Google Maps API adalah sebuah layanan (service) yang diberikan oleh Google kepada para pengguna untuk memanfaatkan Google Map dalam mengembangkan aplikasi. Google Maps API menyediakan beberapa fitur untuk memanipulasi peta, dan menambah konten melalui berbagai jenis services yang dimiliki, serta mengijinkan kepada pengguna untuk membangun aplikasi enterprise di dalam websitenya.Pengguna dapat memanfaatkan layanan-layanan yang ditawarkan oleh Google Maps setelah melakukan registrasi dan mendapatkan Google Maps API Key.Google menyediakan layanan ini secara gratis kepada pengguna di seluruh dunia. Google Maps API merupakan library javacript untuk pemogramannya, dan saat ini versi terakhir dari google maps API adalah versi 3. Versi ini dikatakan tampilannya lebih cepat dari versi sebelumnya khusus untuk browser ponsel dan dapat juga membangun situs web yang dilengkapi peta untuk iphone dan ponsel dengan system operasi android.

Cara menulis program google maps API dengan urutan sebagai berikut :

1. Untuk memasukkan maps API javascript ke dalam HTML kita.

2. Membuat elemen div dengan nama map_canvas untuk menampilkan peta

3. Membuat beberapa objek literal untuk menyiapkan property-property pada peta

4. Menuliskan fungsi javascript untuk membuat objek peta

5. Meng-instal peta dalam tag body HTML dengan event onload [9].

\subsection{Sistem Informasi Geografi (SIG)}

System informasi geografi adalah system informasi khusus yang mengelolah data yang memiliki informasi spasial (bereferensi keruangan). Atau dalam arti yang lebih sempit, adalah system computer yang memiliki kemampuan untuk membangun, menyimpan, mengelola dan menampilkan informasi bereferensi georafis, misalnya data yang didentifikasi menurut lokasinya, dalalm sebuah database. [17]

System informasi geografi dibagi menjadi dua kelompok yaitu manual (analog), dan system otomatis yang berbasis digital computer. Perbedaan yang paling mendasar terletak pada cara pengelolaannya. System informasi manual biasanya menggabungkan beberapa data seperti peta, lembar transparansi untuk tumpang susun (overlay), foto udara, laporan statistic dan laporan survey lapangan. Kesemua data tersebut dikonplikasi dan di analisis secara manual dengan alat tanpa computer.

Sedangkan system informasi geografis otomatis telah menggunakan computer sebagai system pengelolah data memalui proses digitasi. [12]

\section{METODE PENELITIAN}

\subsection{Analisis Sistem}

yang akan dikembangkan ini merupakan sistem pencarian lokasi tempat SPBU dan bengkel di kabupaten kota malang menggunakan perangkat android. Dimana cara kerjanya menggunakan Location Based Service dengan melakukan fungsi navigasi untuk menemukan lokasi SPBU mini dan bengkel yang dipilih dan menampilkan informasi dari tempat yang akan dipilih.

\subsection{Blok Diagram Sistem}

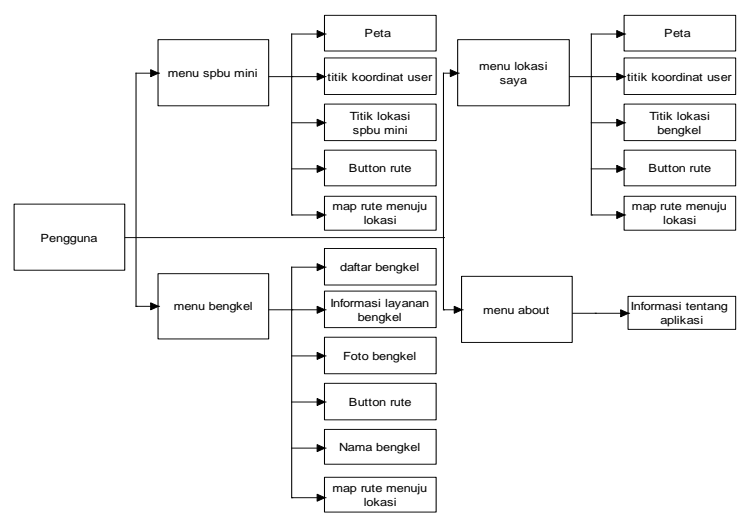

Gambar 2.3 Tampilan Diagram Blok sistem

Dari perancangan tampilan diagram blok ada 4 menu utama yaitu, menu spbu mini, menu bengkel, menu lokasi saya dan menu about. Pada menu spbu mini terdapat 5 fungsi menu yaitu sebagai berikut peta, titik koordinat, titik lokasi spbu mini, button rute dan map rute menuju lokasi. Pada menu bengkel terdapat 6 menu yaitu daftar bengkel, informasi layanan bengkel, foto bengkel, button rute, nama bengkel dan map rute menuju lokasi. Pada menu lokasi saya terdapat 5 fungsi menu yaitu peta, titik koordinat user, titik lokasi bengkel, button rute dan map rute menuju lokasi. Kemudian menu yang terakhir berupa menu about yaitu berisi tentang informasi aplikasi.

\subsection{Flowchart Sistem}

Untuk cara kerja dari aplikasi yang akan dikembangkan tentang aplikasi pencarian lokasi tempat SPBU mini dan bengkel di kabupaten malang, dapat dilihat seperti pada Gambar 3.3. 


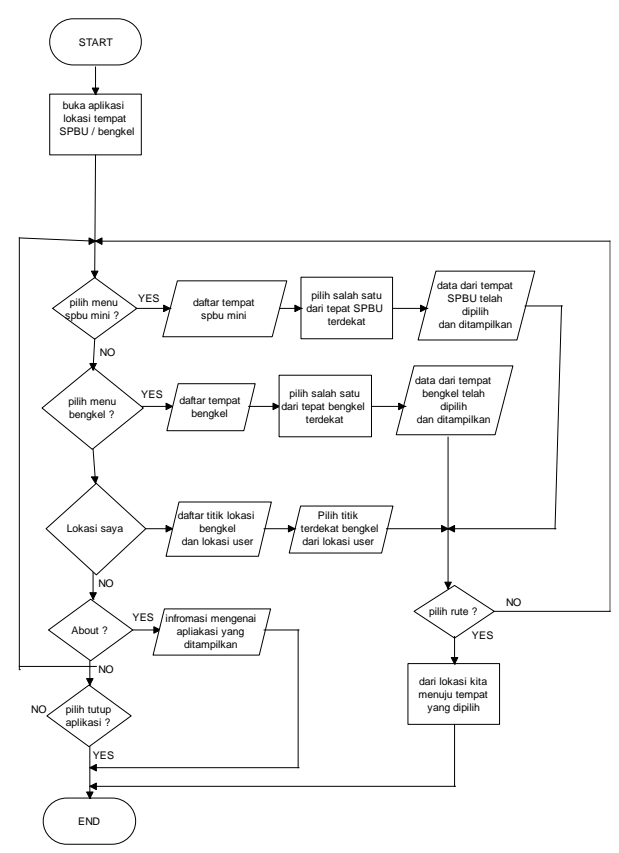

Gambar 3. Flowchart Sistem

Pada Gambar 3.3 ditampilkan flowchart dari sistem/aplikasi yang akan dikembangkan. Dimana aplikasi dimulai dari start lalu membuka aplikasi pencarian lokasi tempat SPBU mini dan bengkel akan ditampilkan menu utama. Menu utama ada 3, yaitu :

1. Jika kita memilih menu SPBU mini, maka sistem akan menampilkan daftar tempat SPBU mini yang ada di kecamatan lowokwaru malang.

Setelah memilih maka akan ditampilkan data/informasi dari tempat SPBU mini telah dipilih dan di tampilkan dalam bentuk map. Jika tidak maka akan kembali ke bagian pilih menu.

2. Jika memilih menu bengkel, maka sistem akan menampilkan daftar tempat bengkel yang ada di kecamatan lowokwaru malang. Setelah memilih maka akan di tampilkan data/informasi dari tempat bengkel telah dipilih dan ditampilkan dalam bentuk map. Jika tidak, maka akan kembali ke bagian pilih menu.

3. Jika memilih menu about, maka system akan menampilkan informasi mengenai aplikasi yang ditampilkan. Jika tidak, maka akan kembali ke bagian pilih menu.

4. Jika sudah ada data dari tempat tujuan SPBU mini, maka akan muncul menu rute dari lokasi kita berada menuju tempat SPBU mini yang telah dipilih. Jika tidak maka akan kembali ke bagian pilih menu.

5. Jika sudah ada data dari tempat tujuan bengkel, maka akan muncul manu rute dari lokasi kita berada menuju tempat bengkel yang telah dipilih. Jika tidak maka akan kembali ke bagian pilih menu.

6. Setelah kita sudah sampai di tempat tujuan, maka langsung ke bagian menu END untuk selesai menggunakan aplikasi.

\section{HASIL DAN PEMBAHASAN}

4.1 Implementasi

Pada tahapan implementasi ini, merupakan proses untuk menjalankan aplikasi yang sudah dibuat. Berdasarkan project yaitu “ aplikasi pencarian spbumini dan bengkel menggunakan metode LBS pada kecamatan lowokwaru malang berbasis android ".

Dari aplikasi ini dapat memberikan layanan informasi pencarian tempat.

\subsection{Tampilan menu utama}

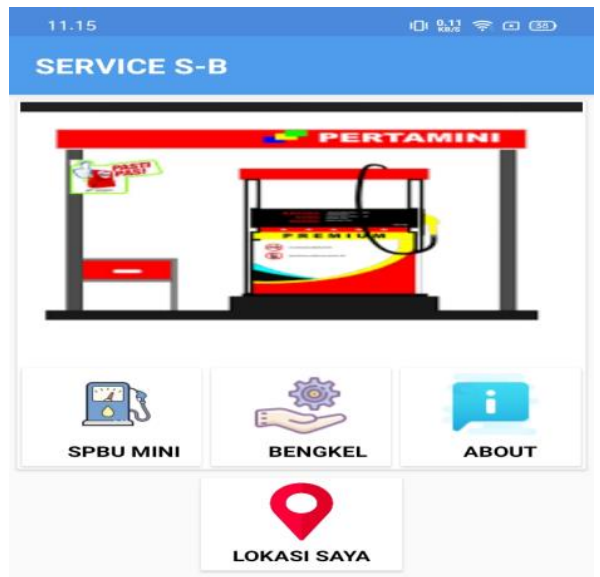

Gambar 4.1 Tampilan Menu utama

Pada tampilan menu yaitu menu utama pada aplikasi pencarian SPBU mini dan bengkel.

\subsection{Tampilan pilih menu bengkel motor}

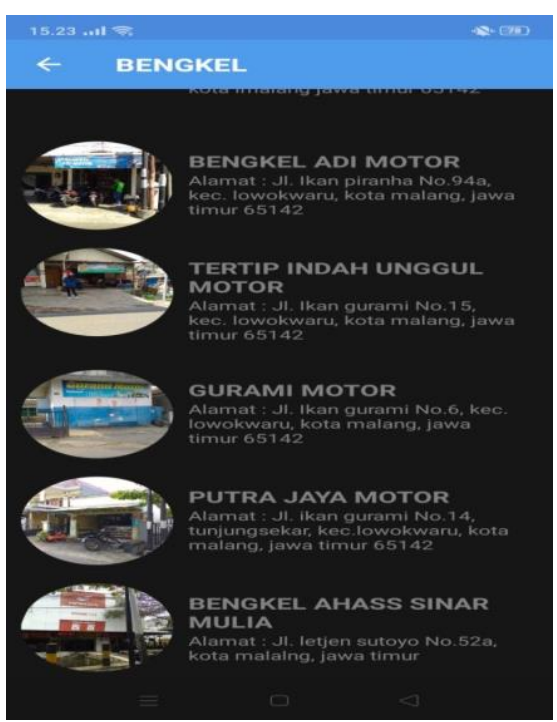

Gambar 4.2 Tampilan pilih bengkel 
Pada tampilan menu ini merupakan tampilan pilihan menu bengkel motor dan pada menu ini juga, memilih salah satu bengkel yang ingin kita tujuan sesuai kebutuhan.

\subsection{Tampilan informasi bengkel}

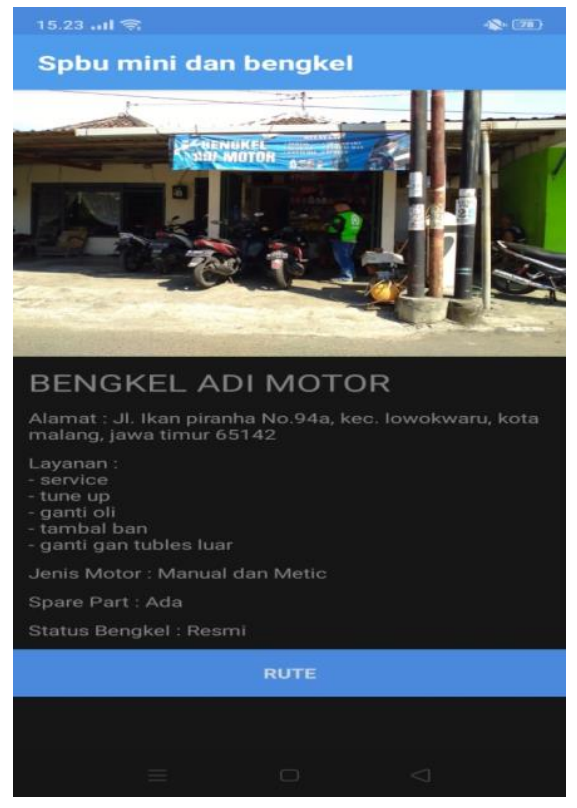

Gambar 4.3 Tampilan informasi bengkel

Pada tampilan menu ini merupakan tampilan tentang informasi bengkel yang kita pilih, informasi ini berupa layanan dari bengkel tersebut, setelah masuk ke dalam menu tersebut sudah ada button rute untuk menuju ke lokasi diinginkan.

\subsection{Tampilan menu rute}

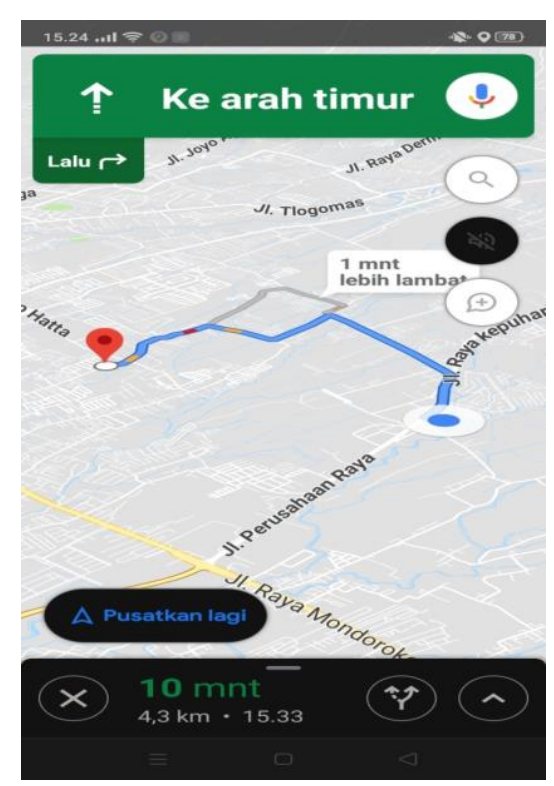

Gambar 4.4 Tampilan menu rute
Pada tampilan menu ini merupakan tampilan rute menuju lokasi bengkel tersebut.

\subsection{Tampilan semua lokasi spbumini}

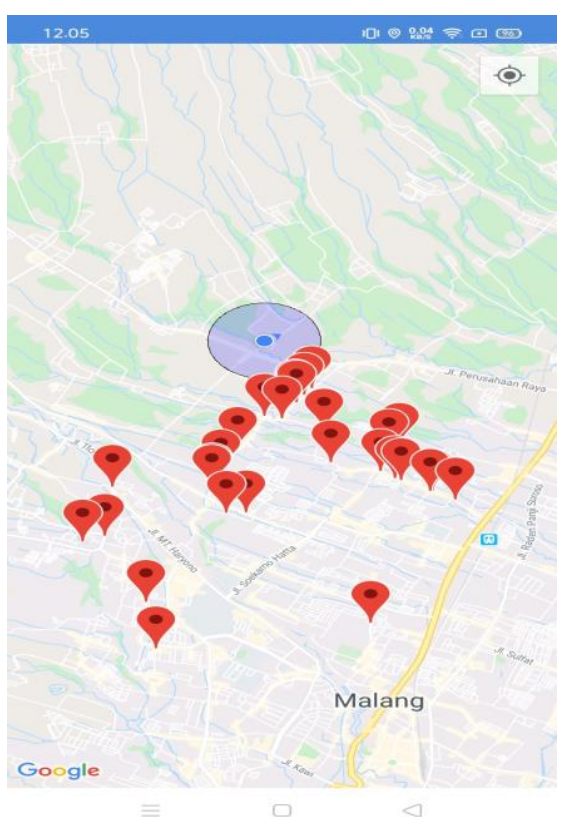

Gambar 4.5 Tampilan semua lokasi spbumini

Pada tampilan menu ini, merupakan tampilan daftar spbumini di kecamatan lowowaru, kota malang.

\subsection{Tampilan pilih salah satu spbumini}

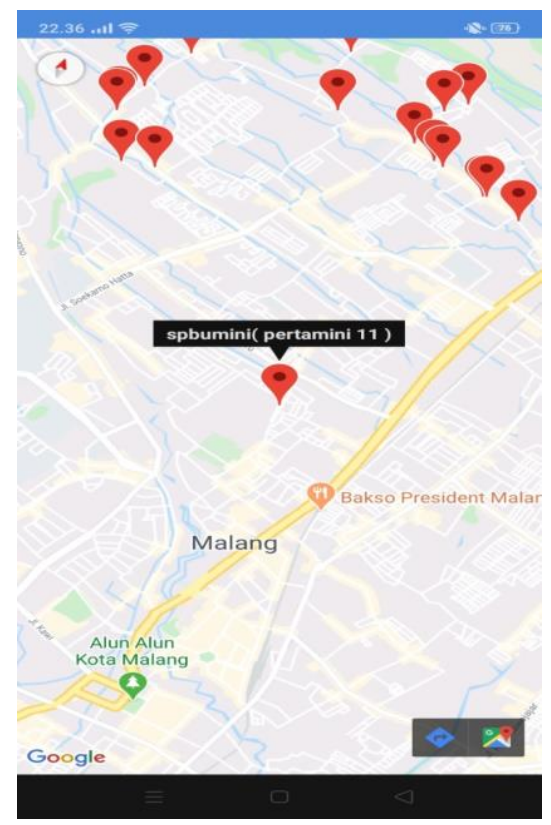

Gambar 4.6 Tampilan pilih salah satu spbumini 
Pada tampilan pilih spbumini ini, merupakan tampilan dimana user memilih salah satu spbumini yang diinginkan.

\subsection{Tampilan rute menuju lokasi}

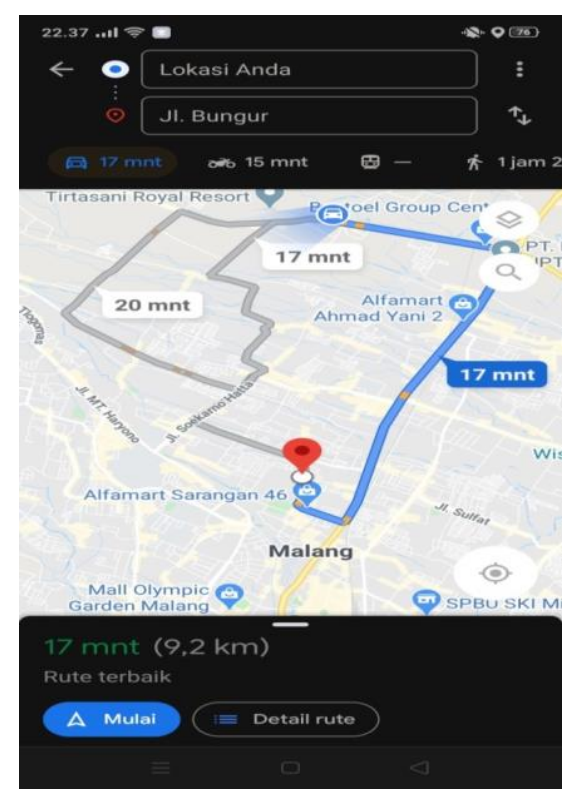

Gambar 4.7 Tampilan rute menuju lokasi spbumini

Pada tampilan menu ini, merupakan tampilan user menuju lokasi spbumini yang telah dipilih.

\subsection{Tampilan Menu Lokasi saya}

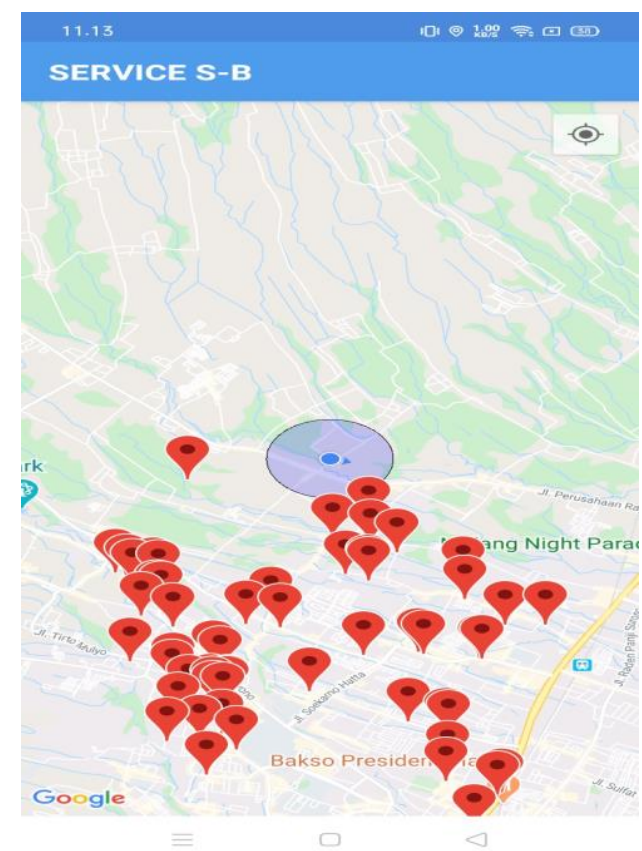

Gambar 4.1 Tampilan Menu utama
Pada gambar 4.1 tampilan menu yaitu menu utama pada aplikasi pencarian SPBU mini dan bengkel.

\subsection{Tampilan Menu Pilih Salah Satu Bengkel}

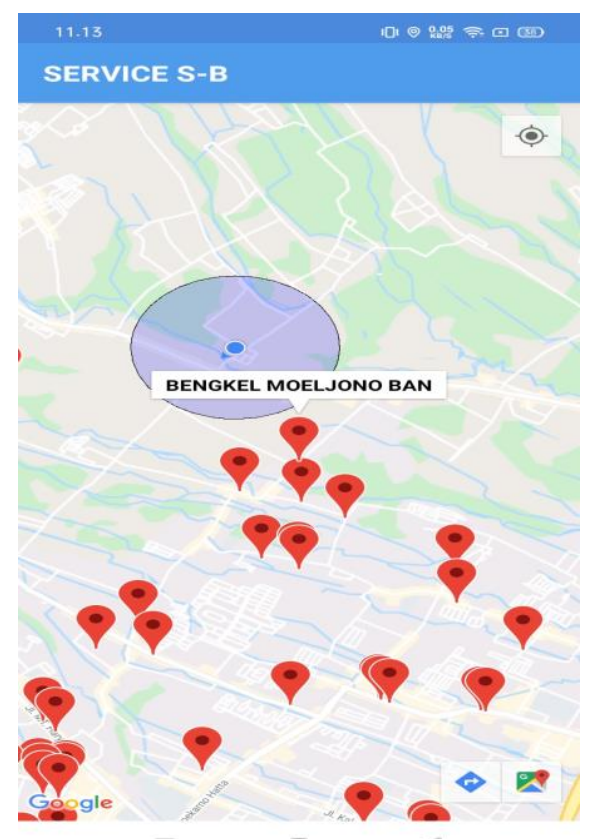

Gambar 4.9 Tampilan Menu Pilih Salah Satu Bengkel

Pada tampilan menu ini, merupakan tampilan informasi lokasi saya yang berada dekat dengan bengkel di kecamatan lowokwaru malang.

\subsection{Tampilan Menu About}

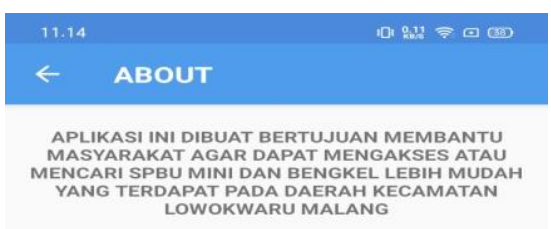

DISUSUN OLEH

JOI MASINI (1418035)

APLIKASI PENCARIAN SPBU MINI DAN BENGKEL
MENGGUNAKAN METODE LOCATION BASED SERVICE
PADA KECAMATAN LOWOKWARU MALANG BERBASIS ANDROID

Gambar 4.8 Tampilan Menu About 
Pada tampilan menu ini, merupakan tampilan informasi tetang aplikasi.

\subsection{Pengujian system}

Pengujian system merupakan tahapan uji coba dari sistem untuk menguji setiap fungsi program yang di buat agar nantinya dapat diambil kesimpulan apakah sistem berjalan dengan baik sesuai tujuan awal pembuatan.

\subsection{Pengujian fungsional sistem}

\begin{tabular}{|c|l|c|c|c|c|c|}
\hline \multirow{2}{*}{ No } & \multicolumn{5}{|c|}{ Fungsi } & \multicolumn{5}{|c|}{ Perangkat } \\
\cline { 3 - 6 } 1 & A & B & C & D & E \\
\hline & $\begin{array}{l}\text { Menampilkan informasi } \\
\text { dari menu pilihan } \\
\text { bengkel }\end{array}$ & $\checkmark$ & $\checkmark$ & $\checkmark$ & $\checkmark$ & $\checkmark$ \\
\hline 2 & $\begin{array}{l}\text { Menampilkan lokasi } \\
\text { pengguna pada peta } \\
\text { spbumini }\end{array}$ & $\checkmark$ & $\checkmark$ & $\checkmark$ & $\checkmark$ & $\checkmark$ \\
\hline 3 & $\begin{array}{l}\text { Menampilkan daftar pilih } \\
\text { bengkel di kecamatan }\end{array}$ & $\checkmark$ & $\checkmark$ & $\checkmark$ & $\checkmark$ & $\checkmark$ \\
\hline 4 & $\begin{array}{l}\text { Menampilkan informasi } \\
\text { rute menuju lokasi }\end{array}$ & $\checkmark$ & $\checkmark$ & $\checkmark$ & $\checkmark$ & $\checkmark$ \\
\hline 5 & $\begin{array}{l}\text { Menampilkan Penanda } \\
\text { dari lokasi user dengan } \\
\text { penanda lokasi spbumini }\end{array}$ & $\checkmark$ & $\checkmark$ & $\checkmark$ & $\checkmark$ & $\checkmark$ \\
\hline 6 & $\begin{array}{l}\text { Menampilkan rute dari } \\
\text { lokasi user ke spbumini }\end{array}$ & $\checkmark$ & $\checkmark$ & $\checkmark$ & $\checkmark$ & $\checkmark$ \\
\hline
\end{tabular}

\section{KESIMPULAN DAN SARAN}

\subsection{Kesimpulan}

Berdasarkan beberapa pengujian yang telah dilakukan didapatkan kesimpulan :

1. Selesainya pembuatan aplikasi pencarian spbumini dan bengkel, dan sudah terujicoba secara fungsional, yaitu semua fitur program dapat berjalan sesuai dengan fungsinya.

2. Pada aplikasi ini, dapat memberikan informasi layanan untuk mencari spbumini dan bengkel, dan juga mempermudah masyarakat khususnya pada akses jalan seperti jalan gang.

3. Hasil dari proses uji coba aplikasi ini dapat berjalan dengan baik yaitu di perangkat android.

\subsection{Saran}

Berdasarkan penelitian yang telah dilakukan, maka penulis dapat memberikan saran-saran untuk pengembangan aplikasi pecarian spbumini dan bengkel menggunakan metode LBS berbasis android, selanjutnya antar lain :

1. Aplikasi pencarian spbu mini dan bengkel ini di buat bertujuan untuk mempermudah masyarakat dalam mencari tempat spbu mini dan bengkel di kecamatan lowokwaru malang khususnya pada akses jalan, seperti jalan gang.

2. Aplikasi pencarian spbu mini dan bengkel mempunyai keunggulan yaitu pada aplikasi tersebut mempunyai titik lokasi user yang bisa berada di lokasi manapun secara otomatis pada mab dan juga user bisa mengetahui lokasi spbu mini atau bengkel yang berada di dekat user dalam satu mab.

3. Aplikasi pencarian spbu mini dan bengkel dapat di jalankan secara online yaitu dengan menggunakan paket data ataupun wifi untuk mengakses maps rute menuju lokasi spbu mini dan bengkel.

4. Aplikasi pencarian tempat spbu mini dan bengkel ini dapat di jalankan minimal pada system operasi android Marshmallow 6.0, android Nougat 7.0, android Oreo 8.0 dan android Q 10.0.

5. Aplikasi pencarian spbu mini dan bengkel ini dapat di jalankan pada resolusi layar mulai dari 5.0 inch sampai 6.52 inch, tetapi terlihat perubahan yaitu perpotongan ukuran layar dan juga tulisan terlihat besar di bagian menu informasi bengkel. Pada resolusi layar mulai dari 7.0 inch sampai dengan 7.3 inch terlihat aplikasi.

\section{DAFTAR PUSTAKA}

[1] Budiman Edy, "PEMANFAATAN TEKNOLOGI LOCATION BASED SERVICE DALAM PENGEMBANGAN APLIKASI PROFIL KAMPUS UNIVERSITAS MULAWARMAN BERBASIS MOBILE", Jurnal Ilmiah ILKOM Vol. 8 No. 3, Desember 2016

[2] Anwar Badrul et al,"IMPLEMENTASI LOCATION BASED SERVICE BERBASIS ANDROID UNTUK MENGETAHUI POSISI USER", Jurnal Ilmiah SAINTIKOM Vol. 13 No. 2, Mei 2014

[3] KOTA MALANG 2016. "KOTA MALANG "https://id.m.wikipedia.org/wiki/kota_malang ( Diakses tanggal 24 Mei 2018) https://id.wikipedia.org/wiki/Kota_Malang

[4] Qusay H. Mahmoud et al, "LOCATION BASED SERVICE". http://digilib.unila.ac. id/13229/12/ (Diakses tanggal 28 Juni 2018)

[5] Suyanto, Asep Herman, "PEMROGRAMAN JAVA : PENGENALAN JAVA", www. Jurnalkomputer.com, 2015

[6] Raharjo, Budi, "BelajarOtodidak MySQL", 1 st ed., Bandung: Informatika Bandung, 2015

[7] Herman yuliansyah, "PERANCANGAN REPLIKASI BASISDATA MYSQL DENGAN MEKANISME PENGAMANAN MENGGUNAKAN SSL ENCRYPTION" https://media.neliti.com/, VOL.8, No 1, januari 2014

[8] Juansyah, Andi. 2015. “PEMBANGUNAN APLIKASI CHILD TRACKER BERBASIS ASSISTED - GLOBAL POSITIONING SYSTEM (A-GPS) DENGAN PLATFORM ANDROID,"JurnalIImiahKomputerdanInformati ka (KOMPUTA) Edisi 1 Volume. 1, Agustus 2015

[9] Anonymous, "Pengenalan JSON", http://www.json.org/json-id.html (diakses tanggal 24 Mei 2017) 
[10] Mahdia, FayadanNoviyanto, Fiftin, "PEMANFAATAN GOOGLE MAPS API UNTUK PEMBANGUNAN SISTEM INFORMASI MANAJEMEN BANTUAN LOGISTIK PASCA BENCANA ALAM BERBASIS MOBILE WEB ( Studi Kasus : Badan Penanggulangan Bencana Daerah Kota Yogyakarta )", JurnalSarjanaTeknikInformatika Volume 1 No. 1, Juni 2013

[11] Windi Eka Yulia R., Dwiretno Istiadi, Abdul Roqib, " PENCARIAN SPBU TERDEKAT DAN PENENTUAN ALGORITMA DIJKSTRA" (study kasus di kabupaten jember), Vol 4, No. 1, maret 2015

[12] https://id.wikipedia.org/wiki/Sistem_informasi_ geografis
[13] http://file.upi.edu/Direktori/FPIPS/JUR._PEND. _GEOGRAFI/195805261986031DEDE_SUGANDI/HAND_OUT_SIG.pdf.

[14] Volume 9 Number 2 November 2019 Page. 3243 Journal Homepage: http://teknois.stikombinaniaga.ac.id/index.php/J BS DOI Link : http://doi.org/10.36350/jbs.v9i2

[15] file://D:/SEMESTER\%20AKHIR/SKRIPSI/SK RIPSI/jurnal/jurnal\%20-\%20SPBU\%20mini.pdf

[16] https://www.researchgate.net/publication/29269 3912_Pencarian_SPBU_Terdekat_dan_Penentu an_Jarak_Terpendek_Menggunakan_Algoritma _Dijkstra_Studi_Kasus_di_Kabupaten_Jember

[17] Nurlita Caesariany Rahardjo, "Pembuatan Sistem Informasi Geografis (SIG) Pencarian Lokasi Bengkel" Vol.2 No.2 (2013) 